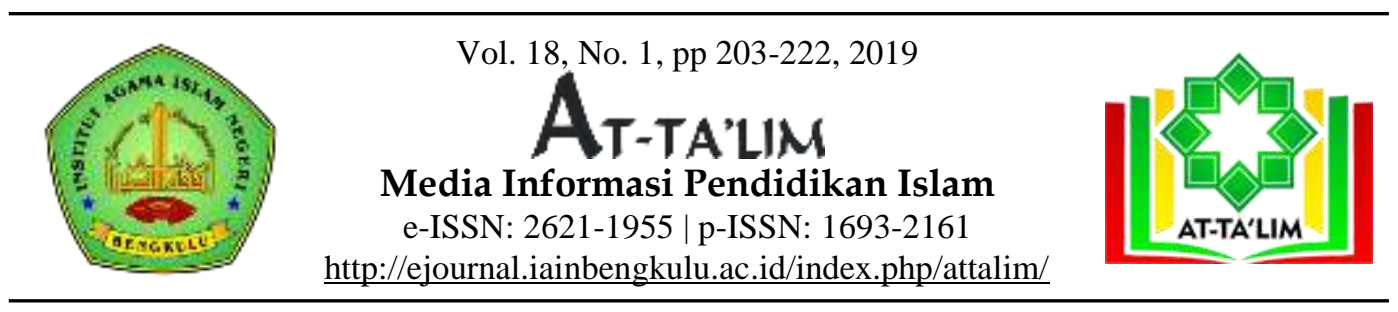

\title{
MANAJEMEN SUMBER DAYA MANUSIA DALAM MENINGKATKAN MUTU PENDIDIKAN DI PONDOK PESANTREN AR-RAHMAH CURUP, KAB. REJANG LEBONG BENGKULU
}

\author{
MUHAMMAD TAUFIQURRAHMAN ${ }^{1}$ \\ 1 taufiq@iainbengkulu.ac.id \\ 1Department of Islamic Education, Faculty of Tarbiyah and Tadris, \\ Institut Agama Islam Negeri Bengkulu \\ Jl. Raden Fatah Kota Bengkulu, Indonesia.
}

Received: June $21^{\text {st }} 2019$

Accepted : June $24^{\text {th }} 2019$

Published: June 25 th 2019

\begin{abstract}
Human Resource Management in Improving Education Quality in Ar-Rahmah Curup Islamic Boarding School, Kab. Bengkulu Rejang Lebong. Islamic boarding schools are one of the Islamic education institutions that apply general subjects and religious subjects. This requires that the teacher or cleric must have the qualifications and competencies that are in accordance with predetermined standards. The quality of education personnel is an important concern in improving the quality of Islamic boarding school education. Human resource management is one step that can be done to select educators who have the competence and qualifications to be able to maximize performance effectively and efficiently. This research is a field research carried out to look deeper into how human resource management in Ar-Rahmah boarding schools. The results of the study show that the management of human resources in improving the quality of education in the Ar-Rahmah boarding school in general has been carried out even though in a simple form. Human resource management in question is First, Planning, Second, Organizing, has been carried out such as HR recruitment based on several stages, simple orientation of personnel and placement of HR. Third, Directing has been carried out such as training and development, work assessment, HR career planning. Fourth, Control (Controling), such as compensation, integration, maintenance, discipline and termination of HR. The inhibiting factor in human resource management is a lack of understanding of the HRM theory comprehensively by the pesantren so that the results obtained are not maximal and the lack of funding and infrastructure
\end{abstract} available to support HRM is more effective and efficient.

Keyword : Human Resource Management, Education Quality, Islamic Boarding Schools

\footnotetext{
Abstrak: Manajemen Sumber Daya Manusia Dalam Meningkatkan Mutu Pendidikan Di Pondok Pesantren Ar-Rahmah Curup, Kab. Rejang Lebong Bengkulu. Pesantren merupakan salah satu lembaga pendidikan Islam yang menerapkan mata pelajaran umum dan mata pelajaran agama. Hal tersebut menuntut guru atau ustad harus memiliki kualifikasi dan kompetensi yang sesuai dengan standar yang telah ditentukan. Kualitas personel pendidikan tersebut menjadi perhatian penting dalam
} 
peningkatan mutu pendidikan pesantren. Manajemen sumber daya manusia merupakan salah satu langkah yang dapat dilakukan untuk menyeleksi tenaga pendidik yang memiliki kompetensi dan kualifikasi agar mampu memaksimalkan kinerja secara efektif dan efisien. Penelitian ini adalah penelitian lapangan yang dilakukan untuk melihat lebih dalam bagaimana manajemen sumber daya manusia di pesantren Ar-Rahmah. Hasil penelitian menunjukkan bahwa manajemen sumber daya manusia dalam meningkatkan mutu pendidikan di pesantren Ar-Rahmah secara umum telah dilaksanakan meskipun dalam bentuk yang masih sederhana. Manajemen sumber daya manusia yang dimaksud adalah Pertama, Perencanaan (Planning), Kedua, Pengorganisasian (Organizing), telah dilakukan seperti rekrutmen SDM berdasarkan beberapa tahapan-tahapan, orientasi personel secara sederhana dan penempatan SDM. Ketiga,Pengarahan (Directing) sudah dilaksanakan seperti pelatihan dan pengembangan, penilaian kerja, perencanaan karier SDM. Keempat, Pengendalian (Controling), seperti kompensasi, integrasi, pemeliharaan, kedisiplinan dan pemberhentian SDM. Faktor penghambat dalam manajemen sumber daya manusia adalah kurang dipahaminya teori MSDM secara komprehensif oleh pihak pesantren sehingga hasil yang didapatkan kurang maksimal serta kurangnya pendanaan dan sarana prasarana yang tersedia untuk menunjang MSDM lebih efektif dan efisien.

Kata Kunci : Manajemen Sumber Daya Manusia, Mutu Pendidikan, Pesantren

\section{To cite this article:}

Taufiqurrahman, M. (2019). Manajemen Sumber Daya Manusia Dalam Meningkatkan Mutu Pendidikan Di Pondok Pesantren Ar-Rahmah Curup, Kab. Rejang Lebong Bengkulu. At-Ta'lim: Media Informasi Pendidikan Islam, 18(1), 203222.

\section{A. INTRODUCTION / PENDAHULUAN}

Pondok pesantren merupakan salah satu lembaga pendidikan Islam tertua yang ada di Indonesia. Pondok pesantren merupakan tempat belajar dan tempat tinggal para santri yang dibimbing oleh seorang kyai yang disini juga berfungsi sebagai pimpinan dan para ustad dalam rangka memperdalam ilmu agama islam secara mendalam dan komprehensip.

Pondok pesantren sebagai salah satu lembaga pendidikan saat ini berkembang dan membutuhkan managemen yang baik. Selain itu juga, dalam penyelenggaraan pendidikan, peningkatan kualitas personel sekolah khususnya para guru atau ustad dan penerapan manajemen sumber daya manusia harus dilakukan agar pelaksanaan program pendidikan yang dirancang sekolah (Pesantren) dapat berjalan efektif dan 
efisien, guna meningkatkan mutu pendidikan menjadi lebih baik dan kompetitif. Namun nyatanya penerapan model manajemen sumber daya manusia belum dilaksanakan secara maksimal, sehingga manajemen sekolah belum dapat menghasilkan tenaga pendidik yang bermutu sesuai kebutuhan dan spesifikasi sekolah yang ada. Misalnya dalam pembuatan perencanaan, belum semua sekolah membuat maupun melaksanakan program dan rencana sumber daya manusia yang tersusun secara rapi sehingga program dan rencana tersebut dapat dijadikan pedoman dalam menindak lanjuti kebutuhan tenaga guru yang diperlukan (Riduan, 2012:228)

Selanjutnya dalam merekrut tenaga guru, terutama tenaga guru yang mengajar pada sekolah swasta. Perekrutan tenaga guru belum sesuai dengan penerapan manajemen yang baik dan masih adanya unsur suka dan tidak suka, nepotisme serta kurang memperhatikan kualitas guru yang benar-benar sesuai dengan tingkat standar yang paling baik. Perekrutan guru

Kemudian permasalahan yang ada di pesantren Ar-Rahmah salah satunya adalah pembagian kerja guru atau ustad di kedua lembaga pendidikan. Selain itu, masalah pengadaan sarana dan prasarana menjadi hambatan pesantren dalam meningkatkan mutu pendidikan. Selain fakor luar tersebut, dalam lingkup organisasi kebutuhan sumber daya manusia (Kemudian disingkat SDM) juga mendapat perhatian dan harus dipenuhi. Kebutuhan sumber daya manusia atau recruitment juga menjadi pertimbangan penting dalam menghasilkan sumber daya yang efektif. Bagaimana proses perekrutan tenaga pendidik harus memiliki persyaratan-persyaratan tertentu agar dapat diberdayakan semaksimal mungkin. Hal tersebut dilakukan dengan maksud untuk memenuhi kebutuhan lembaga dan mempengaruhi perilaku SDM dalam bekerja. Pesantren berupaya meningkatkan mutu pendidikan walaupun terdapat 
keterbatasan-keterbatasan dalam operasional sehingga hal tersebut menjadi permasalahan yang sedang dialami saat ini.

Untuk itu manajemen sumber daya manusia perlu dilakukan secara lebih efektif dan efisien. Hal ini bertujuan untuk mengetahui sejauh mana proses pendidikan berjalan sesuai dengan rencana yang telah dibuat, mengetahui seberapa optimal kinerja semua komponen yang terkait terkhusus mengenai kinerja guru atau ustad, kendala-kendala apa yang dihadapi serta meningkatkan kualitas semua komponen agar tercapainya tujuan pendidikan dan meningkatkan mutu pendidikan di pondok pesantren Ar-Rahmah.

Manajemen sumber daya manusia tersebut dilaksanakan dalam rangka upaya untuk meningkatkan mutu pendidikan. Manajemen sumber daya manusia yang dimaksud merupakan upaya-upaya manajerial apa saja yang dilakukan pihak pondok pesantren dalam rangka meningkatkan kinerja sumber daya yang ada sesuai dengan porsinya dan dilaksanakan seoptimal mungkin. Salah satu indikator peningkatan mutu pendidikan adalah meningkatkan kinerja sumber daya yang ada secara optimal dan sesuai dengan tujuan pendidikan tersebut.

Kemudian hal tersebut diatas juga sejalan dengan pengertian mutu pendidikan itu sendiri yaitu kemampuan lembaga pendidikan dalam mendaya-gunakan sumber-sumber pendidikan untuk meningkatkan kemampuan belajar seoptimal mungkin (Suryadi dan Tilaar, 2004:59). Namun faktanya, berdasarkan observasi awal dapat dikatakan bahwa mutu pendidikan di pondok pesantren Ar-rahmah masih belum baik, terlihat dari sarana dan prasarana pendidikan yang masih sederhana, jumlah siswa yang sedikit, kurangnya peran serta masyarakat dan kurangnya sumber pendanaan.

Berdasarkan fenomena tersebut penelitan ini diharapakan dapat memberikan informasi deskriptif mengenai pelaksanaan manajemen 
sumber daya manusia di pondok pesantren Ar-Rahmah dalam rangka meningkatkan mutu pendidikan.

Penelitian ini bertujuan untuk mengetahui bagaimana pesantren Ar-Rahmah melakukan pelaksanaan sumber daya manusia dalam rangka meningkatkan mutu pendidikan, serta hambatan apa saja yang dihadapi dalam pelaksanaan manajemen sumber daya manusia yang fokus penelitiannya guru atau ustadz.

\section{B. Metode}

Penelitian yang dilakukan oleh peneliti ini merupakan penelitian survey atau merupakan bagian dari penelitian expost facto. Hal ini dikarenakan peneliti tidak melakukan treatment atau perlakuan apapun terhadap objek penelitian. Objek penelitian dibiarkan apa adanya. Hasil temuan di lapangan akan dibahas dan dinarasikan atau di jelaskan ke dalam pembahasan. Sehingga menghasilkan data yang deskriptif yang kualitatif. Adapun data kuantitatif didapatkan untuk melengkapi hasil penelitian. Peneliti menyiapkan instrumen penelitian untuk mengambil data di pesantren. Pengambilan data dilakukan dengan metode observasi dan wawancara sumber daya di lapangan, dalam hal ini adalah di Pondok Pesantren Ar-rahmah Curup.

\section{KAJIAN TEORI}

Kata "Pesantren" menurut Abu Hamid yang dikutip oleh Taufiq, berasal dari bahasa sansekerta yang memperoleh wujud dan pengertian tersendiri dalam bahasa Indonesia. Pesantren berasal dari kata sant yang berarti baik dan tra yang berarti suka menolong. Santra berarti orang baik yang suka menolong. Dengan kata lain, pesantren berarti tempat untuk membina manusia menjadi lebih baik (Taufiq Abdullah, 1996:328).

Klasifikasi lain diajukan oleh Wardi Bakhtiar, dkk. Menurut Bakhtiar (dalam Syamsudduha, 2004:29) dilihat dari sudut pengetahuan 
yang diajarkan, pesantren dapat digolongkan menjadi dua macam. Pertama, pesantren Salafi, yaitu pesantren yang mengajarkan kitab-kitab klasik dan tidak diajarkan pengetahuan umum. Sistem madrasah diterapkan untuk mempermudah teknik pengajaran sebagai pengganti metode sorogan. Kedua, Pesantren Khalafi, yaitu pesantren yang selain memberikan pengajaran kitab Islam klasik juga membuka sistem sekolah umum di lingkungan dan di bawah tanggung jawab pesantren.

Berdasarkan pengertian di atas, pesantren sebagai lembaga pendidikan memerlukan sumber daya yang berkompeten demi menunjang pelaksanaan pendidikan yang efektif dan efisien dalam rangka meningkatkan mutu pendidikan. Sumber daya yang berkompeten, tentu tidak didapat secara instan melainkan dapat dilakukan beberapa cara salah satunya adalah dengan managemen sumber daya manusia (MSDM).

Manajemen sumber daya manusia adalah usaha mewujudkan organisasi yang eksistensinya dibutuhkan oleh masyarakat, melalui perencanaan dan tindakan pemberian pelayanan umum serta pelaksanaan pembangunan untuk kesejahteraan masyarakat, yang berfokus pada peningkatan kemampuan kerja pelaksananya secara berkelanjutan berdasarkan etika dan tanggungjawab sosial yang tinggi dalam bekerja (Chusnul Khotimah dan Muhammad Fathurrahman, 2014: 131).

Gerry Dessler, berpendapat bahwa: "Human resources management is the process acquiring, training, appraising, and compensating employes, and attending to theie labor relations, health and safety and fairness concern". Manajemen sumber daya manusia adalah proses memperoleh, melatih, menilai dan memberikan kompensasi kepada karyawan, memperhatikan hubungan kerja mereka, kesehatan, keamanan dan masalah keadilan (Suparno Eko Widodo, 2015:3-4).

Lingkup kegiatan manajemen SDM sesuai dengan pengelompokkan fungsinya, mencakup kegiatan-kegiatan sebagai berikut: (a) Dalam fungsi perencanaan (Planning) 
Merupakan fungsi penetapan program-program pengelolaan sumber daya manusia yang akan membantu pencapaian tujuan perusahaan, kegiatannya meliputi: pemahaman tujuan dan sasaran organisasi, analisis pekerjaan dan jabatan, penentuan kebutuhan SDM bagi organisasi yang bersangkutan dan perencanaan untuk pemenuhannya serta pengendaliannya.

(b) Dalam Fungsi Pengorganiasian (Organizing)

Merupakan fungsi penyusunan dan pembentukan suatu organisasi dengan mendesain struktur dan hubungan antar para pekerja dan tugas-tugas yang harus dikerjakan, termasuk menetapkan pembagian tugas, wewenang dan tanggung jawab. Kegiatannya mencakup rekrutmen, penyeleksian dan orientasi.

(c) Dalam fungsi pengarahan (Directing)

Merupakan fungsi pemberian dorongan pada para pekerja agar dapat dan mampu bekerja secara efektif dan efisien sesuai dengan tujuan yang telah direncanakan. Pengembangan personel, kegiatannya mencakup: pelatihan dan pengembangan, penilaian kerja dan perencanaan karier.

(d) Dalam fungsi pengendalian (Controlling)

Merupakan fungsi pengukuran, pengawasan dan pengendalian terhadap kegiatan-kegiatan yang dilakukan untuk mengetahui sejauh mana rencana yang telah ditetapkan, khususnya di bidang tenaga kerja, telah di capai. Pemeliharaan personel, kegiatannya mencakup: pengaturan kompensasi, pengaturan tunjangan, pembinaan motivasi, pembinaan kesehatan dan keselamatan, serta hubungan perburuhan dan pemberhentian (Suparno Eko Widodo, 2015:7-8).

Manajemen Sumber Daya Manusia Di Pondok Pesantren ArRahmah Curup.

a. Perencanaan (Planning) Sumber Daya Manusia di Pesantren ArRahmah Curup 
Perencanaan Manajemen sumber daya manusia di pesantren Arrahmah menurut peneliti menggunakan analisis trend yaitu data tahun lampau digunakan untuk memprediksi kebutuhan sumber daya manusia dimasa mendatang. Perencanaan sumber daya manusia dilaksakan apabila data tahun-tahun sebelumnya dianggap masih memiliki kekurangan tenaga kerja sebagai pendidik. Untuk tahun ajaran 2015/2016, menurut pimpinan pondok, tenaga pendidik yang ada dirasa cukup dan mampu melaksanakan tugas dengan efektif dan efisien, sehingga lowongan untuk pengadaan tenaga pendidik tidak dibuka.

Analisis trend yang digunakan pesantren Ar-Rahmah dirasa cukup mudah dan bagus, dikarenakan penggunaan sumber daya manusia internal masih menjadi prioritas berdasarkan data tahun lalu, namun terdapat beberapa kelemahan seperti: bahwa tingkat kebutuhan sumber daya manusia tidak selamanya bergantung kepada data historis, ada faktor-faktor lain yang mempengaruhi yakni perubahan jumlah pendaftaran peserta didik dengan lulusan, yang juga akan mempengaruhi kebutuhan sumber daya manusia di masa mendatang.

Berdasarkan pernyataan tersebut, perencanaan sumber daya manusia di pesantren Ar-Rahmah perlu dilakukan pengembangan agar mampu memaksimalkan kinerja sumber daya yang ada, serta kesiapan pesantren dalam menghadapi perubahan yang mungkin terjadi di masa yang akan datang. Hal tersebut sesuai dengan tujuan perencanaan sumber daya manusia yaitu untuk menjamin penggunaan yang optimal terhadap sumber daya manusia pada pesantren saat ini, menyediakan sumber daya yang dibutuhkan oleh pesantren di masa mendatang baik dalam hal kualitas maupun kuantitas.

Dengan mengedepankan perencanaan yang baik, berarti telah melakukan upaya yang sistematis guna menerapkan fungsi 
manajemen sumberdaya manusia yang pada penerapan fungsi lainnya akan berjalan dengan lancar. Begitu pentingnya fungsi perencanaan ini sehingga kegiatan ini harus dipikirkan oleh pesantren secara lebih tepat dan akurat lagi, agar sumber daya manusia dapat memaksimalkan secara efektif dan efisien dalam rangka meningkatkan mutu pendidikan pesantren.

b. Pengorganisasian (Organizing) Sumber Daya Manusia di Pesantren Ar-Rahmah Curup

\section{1) Rekrutmen Sumber Daya Manusia}

Berdasarkan hasil penelitian proses pelaksanaan rekrutmen sumber daya manusia oleh pesantren Ar-Rahmah telah dilaksanakan dengan baik, hal ini terlihat dari terbaginya langkah rekruitmen menjadi beberapa tahap yaitu: identifikasi tenaga pendidik, sumber calon, metode rekrutmen dan penawaran lowongan.

Identifikasi tenaga pendidik dilakukan untuk melihat kekosongan kerja yang ada. Pada tahapan ini, dilakukan sesuai dengan kondisi yang ada saat itu. Selanjutnya sumber calon, pada tahapan ini pesantren memprioritaskan sumber yang direkrut ialah yang berasal dari alumni pesantren itu sendiri. Hal tersebut merupakan kesepakan antara yayasan, pimpinan pondok dan kepala madrasah, dengan tujuan memberdayakan alumni pesantren yang memiliki kompetensi dan pengalaman.

Adapun metode perekrutan yang dilakukan oleh pesantren ArRahmah adalah dengan pendekatan Compensantory Selection Approach, dimana semua calon tenaga kerja atau peserta seleksi diberikan kesempatan yang sama untuk mengikuti seluruh tahapan seleksi yang telah ditentukan. Tahapan seleksi yang berlaku di pesantren Ar-Rahmah antara lain: seleksi berkas, tes Micro Teaching, baca al-Qur'an dan tes wawancara.

Jika dianalisis, pelaksanaan seleksi dalam rekrutmen sumber daya manusia di pesantren Ar-rahmah telah dilaksanakan dalam bentuk yang 
sederhana tetapi hasilnya dapat maksimal. Hal ini dapat dibuktikan dari data yang ada bahwa tenaga pendidik atau pengajar yang ada di pesantren Ar-rahmah semua berpendidikan S1 bahkan ada beberapa Ustad atau Guru yang telah menyandang gelar Magister atau S2.

\section{2) Orientasi Sumber Daya Manusia}

Pesantren telah melaksanakan orientasi untuk tenaga pendidik baru, namun pelaksanaan orientasi tersebut masih dilaksanakan dengan cara sederhana tanpa adanya pelaksanaan orientasi secara khusus. Hal tersebut berdasarkan pendapat pimpinan pesantren mengingat bahwa calon yang diterima dan dinyatakan lulus sebagian besar adalah alumni pesantren Ar-rahmah, sehingga dirasa telah memahami kondisi pesantren. Walaupun begitu, tujuan orientasi tetap dapat tercapai dengan cukup baik.

\section{3) Penempatan Sumber Daya Manusia}

Penempatan sumber daya manusia ditentukan oleh pesantren dengan melihat latar belakang pendidikan tenaga pendidik tersebut. Penempatan tenaga pendidik sudah sesuai dengan latar belakang pendidikannya, meskipun ada beberapa ustad atau guru yang mengajar mata pelajaran diluar basic keilmuannya. Hal tersebut menurut pimpinan pesantren merupakan bentuk kepercayaan kepada ustad atau guru yang pernah menimba ilmu agama di pesantren, sehingga dianggap berkompeten untuk mengajar mata pelajaran agama seperti muhadarah, mufrodat, imla' dan lain sebagainya.

\section{c. Pengarahan (Directing) Sumber Daya Manusiadi Pesantren Ar- Rahmah Curup}

1) Pelatihan dan Pengembangan Sumber Daya Manusia 
Pengembangan sumber daya manusia di pesantren Ar-rahmah dapat dipetakan menjadi beberapa bagian yaitu pelatihan dan pengembangan, penilaian kerja, perencanaan karir dan promosi.

Pelatihan sumber daya manusia di pesantren Ar-rahmah belum terlaksana dengan maksimal, sebagaimana pelatihan-pelatihan yang ada dalam manajemen sumber daya manusia pada umumnya. Pelatihan bagi sumber daya manusia hanya berupa kelompok kerja guru yaitu kelompok kerja antar sesama guru atau ustad di lembaga yang sama maupun bersama lembaga yang lain. Pelatihan sumber daya manusia di pesantren Ar-rahmah bersifat otonomi, maksudnya adalah pelatihan-pelatihan tersebut diadakan oleh madrasah dengan segala kegiatan didalamnya. Secara umum pelatihan bagi sumber daya manusia bagi pesantren Arrahmah masih sangat sederhana.

Begitu pula dengan pengembangan sumber daya manusiannya, dilakukan secara mandiri pesantren belum memberikan wadah pengembangan bagi tenaga pendidik, sehingga tenaga pendidik secara mandiri mengembangkan kemampuan dan kompetensi yang dimiliki, diluar bantuan dari pesantren.

\section{2) Penilaian Kerja Sumber Daya Manusia}

Pesantren Ar-rahmah telah melakukan penilaian kerja sumber daya manusia walaupun penilaian yang dilakukan relatif sederhana. Penilaian yang dimaksud berupa penilaian kerja tenaga pendidik yang dibahas tiap rapat semester, dengan melihat kinerja selama satu semester tersebut, tenaga pendidik diberi saran, masukan, kritikan bahkan teguran atas kinerja yang telah ditunjukkan selama ini. Walaupun

\section{3) Perencanaan Karier Sumber Daya Manusia}

Perencanaan karir sumber daya manusia di pesantren Arrahmah belum terlaksana maksimal sesuai dengan teori yang ada. 
Perencanaan karir bagi sumber daya manusia di pesantren Ar-rahmah dibagi menjadi dua. Pertama, perencanaan karier bagi tenaga pendidik yang mengajar di madrasah dan pesantren, diarahkan untuk melengkapi administrasi dan keperluan lain untuk mendapatkan surat keputusan dari kemenag mengani status guru tidak tetap madrasah yang ada di bawah naungan pesantren Ar-rahmah. Tujuannya adalah agar tenaga pendidik mendapatkan pengakuan dari kedua lembaga tersebut yang akan menunjang kompensasinya dikemudian hari.

Kedua, perencanaan karier bagi tenaga pendidik khusus di pesantren. Belum dilaksanakan perencanaan karier dengan maksimal tetapi masih dalam bentuk yang minim dan sederhana, dikarenakan keterbatasan yayasan dalam mewadahi sumber daya manusia untuk merencanakan karier kedepannya. Namun, yang perlu diperhatikan adalah upaya yang dilakukan pesantren untuk dapat menggunakan keahlian personel sumber daya manusia yang ada dengan lebih baik, yaitu dengan memberikan kepercayaan kepada personel alumni pesantren untuk mengajarkan mata pelajaran agama, menciptakan komunikasi yang baik antar sesama sumber daya manusia untuk menciptakan lingkungan yang hangat dalam interaksi edukasi seharihari dan meningkatkan efektivitas manajemen sumber daya manusia.

\section{4) Promosi, Demosi atau Transfer Sumber Daya Manusia}

Promosi, demosi, atau transfer sumber daya manusia di pesantren Ar-rahmah dilaksanakan dengan cara yang sederhana. Hal ini terlihat dari pendapat pimpinan pesantren bahwa tenaga pendidik yang memiliki kinerja baik dan terus meningkat diberikan tanggungjawab lebih yaitu sebagai bagian dari pengurus dalam organisasi pesantren. Namun, secara empiris, pelaksanaan promosi tidak berlangsung dengan cara yang formal, melainkan dengan cara yang lebih sederhana yaitu kekeluargaan. Tenaga kerja yang dianggap mampu mengemban tugas tambahan sebagai pengurus dalam struktur 
organisasi pesantren diajukan kepada yayasan dan kemudian diberikan tanggungjawab untuk menjalankan tugasnya dengan efektif dan efisien. Hal tersebut adalah salah satu bentuk promosi tenaga pendidik untuk mendapat pengalaman dalam mengurus organisasi pesantren dalam rangka ikut meningkatkan mutu pendidikan pesantren.

Untuk demosi dan transfer, keduanya dilaksanakan kepada tenaga pendidik yang indisipliner. Dimana, jika terjadi pelanggaran peraturan atau disiplin yang berlaku di pesantren, maka demosi dan transfer sumber daya manusia dapat dilakukan sesuai tingkat pelanggaran yang diperbuat.

d. Pengendalian (Controlling) Sumber Daya Manusiadi Pesantren Ar-

\section{Rahmah Curup}

\section{1) Kompensasi Sumber Daya Manusia di pesantren Ar-Rahmah}

Kompensasi sumber daya manusia yang diberikan oleh pesantren berasal dari yayasan dan kemenag Rejang Lebong. Kompensasi yang diberikan berupa gaji bulanan untuk semua tenaga pendidik dan tunjangan jabatan untuk tenaga pendidik yang menjabat sebagai pengurus dalam struktur organisasi pesantren Ar-rahmah.

Kompensasi yang didapat oleh tenaga pendidik cukup, dan ada kesan bahwa kompensasi tersebut masih kurang untuk dapat mensejahterakan tenaga pendidik. Hal tersebut sesuai dengan pendapat pimpinan pondok bahwa kompensasi yang diberikan kepada pendidik adalah sama, tanpa ada perbedaan jam mengajar untuk di pondok pesantren sedangkan untuk di madrasah kompensasi yang diberikan merupakan kebijakan kepala madrasah yang telah berkoordinasi dengan yayasan.

Terdapat kendala dalam pemberian kompensasi sumber daya manusia di pesantren Ar-rahmah yaitu sering terjadinya 
keterlambatan pembayaran gaji kepada tenaga pendidik dikarenakan keterbatasan yang ada pada yayasan.

e. Faktor-faktor Penghambat Manajemen Sumber Daya Manusia dalam Meningkatkan Mutu Pendidikan di Pesantren Ar-Rahmah Curup, Bengkulu

Pertama, faktor penghambat manajemen sumber daya manusia adalah kurang dipahaminya pengertian, proses dan sistem manajemen sumber daya manusia secara komprehensif oleh pesantren, sehingga pelaksanaan manajemen sumber daya yang telah dilaksanakan masih bersifat sederhana. Kedua, hal yang paling krusial adalah masalah pendanaan. Untuk melaksanakan manajemen sumber daya manusia yang komprehensif sesuai dengan teori manajemen sumber daya manusia yang ada diperlukan dana yang tidak sedikit. Mengingat pesantren Ar-rahmah merupakan lembaga pendidikan swasta, maka sumber dana yang didapat adalah usaha mandiri pesantren melalui yayasan dan bantuan dari alumni.

Ketiga, peningkatan mutu pendidikan bukan hanya melalui manajemen sumber daya manusia saja namun dari semua sisi masih perlu pengembangan lagi. Hal tersebut merupakan bentuk keseriusan pesantren terhadap peningkatan mutu pendidikan pesantren.

Keempat, sarana dan prasarana yang masih kurang. Sarana dan prasarana menjadi kendala dalam pelaksanaan manajemen sumber daya manusia, karena kurang optimalnya pelaksanaan manajemen sumber daya manusia yang memerlukan sarana dan prasarana sebagai pendukung.

Manajemen Sumber Daya Manusia dalam Meningkatkan Mutu Pendidikan di Pesantren Ar-Rahmah Curup, Bengkulu 
Berdasarkan hasil penelitian mengenai manajemen sumber daya manusia di pesantren Ar-rahmah, dapat disimpulkan bahwa pelaksanaan MSDM telah dilaksanakan meskipun masih sederhana. Dari hasil penelitian didapati bahwa ke delapan fungsi pelaksanaan MSDM yaitu perencanaan, rekrutmen, pengembangan, kompensasi, integrasi, pemeliharaan, kedisiplinan dan pemberhentian di pesantren Ar-rahmah sudah dilakukan meski masih ada beberapa bagian yang belum dilaksanakan maksimal sesuai dengan teori MSDM pada umumnya. Pelaksanaan MSDM tersebut bertujuan untuk melihat kinerja sumber daya manusia yang efektif dalam rangka meningkatkan mutu pendidikan pesantren.

Mutu pendidikan yang dilihat adalah mutu dalam konteks hasil manajemen sumber daya manusia yang mengacu pada kinerja sumber daya manusia secara efektif dan efisien dalam kurun waktu tertentu. Hal itu harus diupayakan agar tepat sasaran. Adapun bentuk upaya peningkatan mutu pendidikan yang dilakukan antara lain:

a) Peningkatan kesejahteraan guru.

b) Pengadaan sarana dan prasarana pembelajaran.

c) Pengawasan terhadap program pendidikan di sekolah.

Berdasarkan hasil penelitian didapati bahwa mutu pendidikan pesantren Ar-rahmah masih perlu ditingkatkan mengingat ketiga upaya tersebut belum mampu dilaksanakan dengan hasil yang maksimal. Seperti: Pertama, peningkatan kesejahteraan guru, dalam hal ini pesantren Ar-rahmah melalui manajemen sumber daya manusia telah berupaya untuk meningkatkan kesejahteraan tenaga pendidik dalam bentuk pemberian tunjangan kepada guru, mengingkatkan kompetensi guru dengan kelompok kerja guru dan pemberian alokasi waktu yang disesuaikan dengan kebutuhan mengajar guru.

Kedua, pengadaan sarana dan prasarana sebagai penunjang sumber daya manusia sebagai tenaga pendidik agar mampu bekerja lebih efektif 
dan efisien. Pesantren Ar-rahmah telah berupaya mengadakan sarana dan prasarana meski dalam keterbatasan. Hal ini terbukti dari ketersediaan sarana prasarana saat ini seperti ruang kelas yang layak, lapangan basket, kantor, kantin santri, asrama putra, asrama putri, masjid, UKS dan ruangan lainnya. Namun, yang menjadi kekurangan saat ini adalah ketersediaan laboratorium yang belum mampu diadakan pihak pesantren dikarenakan keterbatasan dana. Menurut pimpinan pesantren, selama ini dana pembangunan di dapatkan dari yayasan dan alumni yang bersedia memberikan bantuan. Untuk pemerintah, baru satu kali memberikan bantuan untuk pembangunan kelas untuk belajar.

Ketiga, pengawasan jalannya proses pendidikan di pesantren. Menurut pimpinan pesantren pengawasan jalannya proses pendidikan dilakukan oleh yayasan rutin selama satu bulan satu kali. Hal tersebut sebagai upaya yayasan untuk mengontrol jalannya pendidikan di pesantren agar tetap berada di koridor yang tepat sesuai dengan tujuan yang ingin dicapai dan sesuai dengan visi misi pesantren dalam rangka menjamin mutu pendidikan di pesantren Ar-rahmah.

Menurut peneliti manajemen sumber daya manusia dalam rangka meningkatkan mutu pendidikan di pesantren Ar-rahmah secara umum telah dilaksanakan. Namun, masih terdapat banyak kekurangan di beberapa sisi, yang harus dikembangkan oleh pesantren agar kedepannya pesantren mampu meningkatkan pemberdayaan sumber daya manusia yang ada. Hal tersebut semata-mata dilaksanakan dalam rangka meningkatkan mutu pendidikan di pesantren. Karena kriteria pendidikan bermutu dapat dilihat dari aspek pelayanan penyelenggaraan pendidikan yang baik, ketersediaan fasilitas sarana dan prasarana yang menunjang proses pendidikan di pesantren, kuantitas dan kualitas tenaga pendidik, prestasi akademik siswanya, kepuasan dan kepercayaan orang tua pada sistem pendidikan yang ada di pesantren dan kemampuan kompetensi 
lulusannya dalam kehidupan, yakni menjadi insan yang berilmu dan beragama.

\section{KESIMPULAN}

Manajemen Sumber Daya Manusia dalam meningkatkan mutu pendidikan di Pesantren Ar-rahmah telah dilaksanakan dalam bentuk yang sederhana, walaupun hasil yang didapat belum maksimal. Hal tersebut dikarenakan terdapat beberapa langkah dalam manajemen sumber daya manusia yang belum dilaksanakan sesuai dengan ketentuan dan teori MSDM yang ada.

Kendala yang dihadapi dalam pelaksanaan manajemen sumber daya manusia di pesantren Ar-rahmah antara lain adalah kurang dipahaminya proses pelaksanaan manajemen sumber daya manusia secara komprehensif dan sesuai dengan teori yang ada. Kemudian masalah pendanaan atau sumber dana yang dirasa tidak efisien untuk melakukan manajemen sumber daya manusia mengingat pendanaan yang ada saat ini tidak mencukupi. Kendala-kendala lain ialah kurangnya sarana dan prasarana pendukung untuk melaksanakan manajemen sumber daya manusia yang efektif, sehingga manajemen sumber daya yang dilaksanakan masih bersifat sederhana sesuai dengan kemampuan pesantren.

\section{E. REFERENCES / DAFTAR PUSTAKA}

Abdullah, T., (1996), Agama dan Perubahan Sosial, Jakarta: Raja Grafindo Persada.

Widodo, S. E.., (2015), Manajemen Pengembangan Sumber Daya Manusia, Yogyakarta: Pustaka Pelajar

Khotimah, C. \& Fathurrohman, M., (2014). Komplemen Manajemen Pendidikan Islam: Konsep Integratif Pelengkap Manajemen Pendidikan Islam, Yogyakarta: Teras 
Mantja, W., (2005). Etnografi: Desain Penelitian Kualitatif Dan Manajemen Pendidikan, Malang: Wineka Media

Manullang, M., (2012). Dasar-dasar Manajemen, Yogyakarta: Gajah Mada University Press

Margono. S., (2003). Metodologi Penelitian Pendidikan, Jakarta :RenikaCipta

Moleong, L. J., (2008). Metode Penelitian Kualitatif, Bandung: Remaja Rosda Karya

Muhadjir, N., (2002), Metode Penelitian Kualitatif (Edisi IV), cet.I, Yogyakarta: Rake Sarasin

Mulyono., (2008). Manajemen Administrasi dan Organisasi Pendidikan, Yogyakarta: Ar-Ruzz Media

Nasution, S., (1998). Metode Penelitian Naturalistik Kualitatif, Bandung: Tarsito

Riduan., (2000). Manajemen Pendidikan, Bandung: Alfabeta

Margono. S. (2003)., Metodologi Penelitian Pendidikan, Jakarta: Renika Cipta

Sugiono., (2007). Memahami Penelitian Kualitatif, Bandung: Alfabeta

Sukardi., (2004). Metodologi Penelitian Kualitatif: Kompetensi dan Praktiknya, Jakarta: Bumi Aksara

Suryadi \& Tilaar, (2004). Manajemen Pendidikan di Sekolah, Jakarta: Rineka Cipta

Syamsudduha., (2004), Manajemen Pesantren (Teori dan Praktik), Yogyakarta: Graha Guru 